International Journal of Current Advanced Research

ISSN: O: 2319-6475, ISSN: P: 2319 - 6505, Impact Factor: SJIF: 5.995

Available Online at www.journalijcar.org

Volume 6; Issue 3; March 2017; Page No. 2465-2468

DOI: http://dx.doi.org/10.24327/ijcar.2017.2468.0029

Research Article

\title{
GREEN TECHNOLOGY VS ENVIRONMENTAL SUSTAINABILITY IN INDIA- AN OVERVIEW
}

\author{
Gangadhar B and Ramakrishna Naidu G
}

Department of Environmental Sciences S.V. University, Tirupati - 517502 Andhra Pradesh, India

\begin{tabular}{l}
\hline A R T I C L E I N F O \\
\hline Article History: \\
Received $10^{\text {th }}$ December, 2016 \\
Received in revised form $7^{\text {th }}$ January, 2017 \\
Accepted $11^{\text {th }}$ February, 2017 \\
Published online $28^{\text {th }}$ March, 2017
\end{tabular}

Kye Words:

Green Technology, Environmental

Sustainability, Globalization and Exploitation.

\begin{abstract}
A B S T R A C T
Various technologies are being invented and used by Human Civilization which supports day to day activities. The adoption of technology is limited and has adverse effects on environment and human civilization. Therefore, scope exists for application of new technologies which are more eco and environmental friendly for supporting day to day activities of the present lifestyle. However, new technologies are more efficient and environment friendly due to increased awareness and recent development in research areas of energy management. These technologies are characterized as green or clean technology. Green technologies involve: energy efficiency, recycling, safety and health concerns, renewable resources, and many more.

With the increased efforts in the direction of globalization across the globe also increased the level of competition among various companies in various domains of work and in between governments for the sake of development. The fact that the globalization has taken the world to new heights of development and it has also increased the pace of development in many developing countries especially, India and China. For the sake of globalization and development we are continuously exploiting our mother nature, the environment. People concerned with environment and ecology suggests that if this rate of exploitation continues then the day is not so far when earth and its environment will be not suitable for sustainable life. That's where the term green technology comes into lime light which uses technology in such a way that in one end development which is a result of globalization continues and on the other end the level of negative environmental impact is reduced to its minimum level. This paper will critically review literature on current environmental sustainability practices and the role of green technologies in sustainable development. This paper also reviews various green technologies from view point of adaptability and implementation issues for modern living towards sustainable environment.
\end{abstract}

Copyright $@ 2017$ Gangadhar B and Ramakrishna Naidu G. This is an open access article distributed under the Creative Commons Attribution License, which permits unrestricted use, distribution, and reproduction in any medium, provided the original work is properly cited.

\section{INTRODUCTION}

Green technology is the technology which is environment and eco-friendly, developed and used in such a way so that it should not disturb our environment and conserves natural resources which lead to sustainable development. However some people refer green technology as environmental technology and clean technology which is intended to protect environment and mainly to conserve natural resources. The present expectation is that this field will bring innovation changes in daily life of similar magnitude of information technology. Green technology is based on the four pillars on various sectors. Government takes initiatives to promote green technology and introduced many fiscal incentives that generate electricity from renewable sources.

\section{*Corresponding author: Gangadhar B}

Department of Environmental Sciences S.V. University, Tirupati 517502 Andhra Pradesh, India
Import duty and sales tax exemption for solar systems equipment, sales tax exemption for the purchase of solar heating system equipment from local manufacturers. Ministry of energy has also implemented national level annually month to raise awareness about renewable energy \& promote green technology.

Green Technology is the development and application of products, equipment and systems used to conserve the natural environment and resources, which minimize and reduces the negative impact on environment by human activities. Green Technology refers to products, equipment or systems which satisfy the following criteria:

1. It minimizes the degradation of the environmental segments and natural resources;

2. It has zero or low greenhouse gas (GHG) emission is safe for use and promotes healthy and improved environment for all forms of life;

3. It conserves the use of energy and natural resources;

4. It promotes the use of renewable resources. 
The following are the goals of green technology.

- To meet and cater the needs of society in such a way without damaging or depleting natural resources on earth is the main objective of green technology.

- To meet present needs without making any compromises. Focus is being shifted on making products that can be fully reclaimed or reused. By changing patterns of production and consumption, steps are being taken to reduce waste and pollution, as one of the important goals of green technology.

- It is essential to develop alternative technologies to prevent any further damage to health of human beings and other living beings and its advantages and their disadvantages of the green technology.

\section{METHODOLOGY}

Through Literature survey has been done to know the present approaches in implementation of Green Technologies by the Government and how they influences the environment and promotes environment sustainability.

\section{Importance of Green Technology}

Green technology, an environmentally friendly technology is developed and used in a way that protects the environment and also conserves natural resources. A part of the renewable energy branch of the environmental technology, the importance of green technology cannot be ignored. We have come to a point, where we need to pause and reflect on the growing green technology importance and why it is going to be important for humanity. With many reasons behind green technology importance, perhaps volumes can be written and spoken on the subject. Whether it is the growing importance of green technology in the industry or at homes, it is certain that things need to be done fast. It does not take a rocketscientist to state that mankind has to do something about clean environment and save energy resources. Going green can only help us come out of the present tough situation. Before things turn for the worst, we should realize the green technology importance to solve this problem [1-2]

The main four pillars of green technology policy are

- Energy - Seek to attain energy independent and promote efficient utilization;

- Environment - Conserve and minimize the impact on the environment;

- Economy - Enhance the national economic development through the use of technology; and

- Social - Improve the quality of life for all [3].

\section{DISCUSSION}

\section{Green technologies in Brief}

Solar energy, wind energy, ocean energy, energy conservation, Bioremediation are some of the green technologies which are intended to protect environment and conserve natural resources.

\section{Solar Energy}

Solar power is quickly becoming a major contender in the race for renewable energy. About 89 petawatts of power are available at any given point in time, 6,000 times the power consumed by all human civilization. In 14.5 seconds, the earth absorbs as much solar energy as humanity consumes in 24 hours. There are various application of solar energy. For example Solar energy can be harnessed for water distillation through evaporation. After placing translucent material over a moist patch of ground, in a manner that does not allow air to escape, the evaporated water which becomes a liquid on the surface of the material. This water can then be gathered into a cup or another container of some sort. The water produced is pure, and can be safely drunk.

India's solar power generation capacity stood at over $9 \mathrm{GW}$ as on December 31, 2016 with Tamil Nadu having the largest output capability followed by Rajasthan and Gujarat. "As on December 31, 2016, Gujarat (1.16 GW), Rajasthan (1.32 GW), and Tamil Nadu (1.6 GW) have crossed $1 \mathrm{GW}$ solar installations..., while Andhra Pradesh (0.98 GW), Telangana $(0.97 \mathrm{GW})$ and Madhya Pradesh $(0.84 \mathrm{GW})$ are close to these states. Solar power development varies from state to state depending on solar irradiance, availability of conducive state policy for the sector, availability of land, cost of financing and business environment such as willingness of DISCOMS to purchase the solar power, power evacuation infrastructure, etc.

The government is promoting solar energy through fiscal and promotional incentives such as capital and/or interest subsidy, tax holiday on the earnings for 10 years, generation-based incentive, accelerated depreciation, viability gap funding (VGF), financing solar rooftop systems as part of home loan, concessional excise and custom duties, preferential tariff for power generation from renewables, and foreign investment up to 100 per cent under the automatic route, etc. This apart, the government has been supporting solar manufacturing by way of various mechanisms such as Modified Special Incentive Package Scheme (M-SIPS) of the Ministry of Electronics \& Information Technology (MeitY) [8].

\section{Wind Energy}

Wind energy is a capable source for renewable energy, but the uncontrollable nature of the wind presents concerns. Unsteady winds do not provide the best aerodynamic performance for wind turbines and sudden, uneven gusts can lower the productivity of the blades.

Under National Wind Resource Assessment programme, Ministry through National Institute of Wind Energy, Chennai (erstwhile Centre for Wind Energy Technology (C-WET)) and State Nodal Agencies had installed and monitored 794 dedicated Wind Monitoring Stations (WMS) of height ranging from $20 \mathrm{~m}$ to $120 \mathrm{~m}(20 \mathrm{~m}, 25 \mathrm{~m}, 50 \mathrm{~m}, 80 \mathrm{~m}, 100 \mathrm{~m} \&$ $120 \mathrm{~m}$ ) throughout the country as on 31.12 .2014 . Initially the wind monitoring was carried out only in known windy areas. Now it is extended to new/ uncovered areas which are not explored in earlier projects to complete the Indian Wind resource mapping. Further hundreds of private winds monitoring stations are also operational in the country. Based on the analysis on the data collected from these 700 plus WMS, it is found that 237 stations have economically preferable wind power potential greater than $200 \mathrm{~W} / \mathrm{m} 2$ [9].

\section{Ocean Energy}

At present, the possibility of globally-dominant, large-scale, ocean energy plants is just that: an attractive possibility. As with any new technology, existing marine energy devices possess limitations. Their construction and maintenance may 
currently prove financially demanding, and not all sites are suitable for their effective implementation. However, these problems will likely soon see solutions, and ocean energy conversion may soon produce as much as, if not more electricity than other forms of green energy, such as traditional wind power systems.

\section{Energy Conservation}

Energy Conservation can be achieved by the use of equipment which requires lesser amount of energy, following low consumption of electricity; thereby reducing the use of fossil fuels to generate the same. Energy conservation and efficiency are both energy reduction techniques.

\section{Water Treatment}

It is a step by step processes used to make the water more suitable for the end users. The use of such water categorized broadly among drinking water, industrial use, and medical use and also for other uses. The main objective of water treatment is the removal of pollutants in the water, so as to make it suitable for further use. From the viewpoint of environment water treatment is used to reduce the adverse impact of the water returning to the environment after its use. Settling, filtration, disinfection, coagulation are some of the basic physical and chemical processes employed for water treatment. Also aerated lagoons, activated sludge or slow sand filter are some prominent process.

\section{Environmental Remediation}

Environmental Remediation deals with the removal of pollutants from the natural resources such as ground water, water reserves on earth surface, soil for the protection of environment and human health.

\section{Attaining Environmental Sustainability via Green technologies}

By using various green technologies in a systematic way with strategic plan there is a probability of attaining environmental sustainability which helps in conservation of natural resources and protection of environment. The technologies like fuel cell and renewable energies are getting much exposure as green technologies as they can be easily adapted in the existing infrastructure. Green Transport is an application of fuel cell and renewable energies, so the adaptability of this depends on how well fuel cell and renewable energies are implemented.

The risk associated with "dirty" technologies such as the petroleum products are alarmingly raising. The "clean" technologies as a result, are expected to provide lower risk alternatives. Most of the governing bodies in developing and developed countries are investing large amount of money into clean energy market and pursuing businesses facilitating renewable energy technologies that are energy efficient. One of United Nations Environmental Program's report states, in 2006, \$2.9 billion was invested in clean technologies (mostly in wind, solar and other low-carbon energy technologies), which was $80 \%$ higher over 2005. As climate change threat has spurred green investing, UNEP coins this trend as the "world's newest gold rush" $[5,6]$.

Green Technology (GT) covers a broad group of methods and materials for generating energy to non-toxic cleaning products. The main reason, this area has been significantly important is because most of the people expect a dramatic innovation and changes in their livelihood. The development of alternative technology should attempt to benefit the planet truly protecting the environment and mother earth. This technology meets the needs of society in ways that can continue indefinitely into the future without damaging or depleting natural resources. In terms of the technology that can create products, which can be fully reclaimed or re-used, such cradle to grave cycle of manufacturing has successfully reduced waste and pollution by changing patterns of production and consumption. The innovations in technology have aroused interest in developing alternative fuels as a new means of generating energy and energy efficiency. Furthermore, GT is the application of green chemistry and green engineering, one of the most exciting fields of technology, which is supposed to transform the way that everything in the world is manufactured.

The world relies on large amounts of energy. The level of dependency has increased on fossil fuels such as oil, gas and coal. Energy is important for sustaining the planet and therefore the task before us is to assess and utilize various sources of energy that occur naturally in the environment. Green technologies definitely shows prominent results in utilizing various alternative energy resources to overcome the present energy demands and also promotes sustainable development.

\section{CONCLUSION}

From the above discussion we can conclude that green technology is a must in today's scenario to achieve environmental sustainability and also to lead sustainable life. Because the conventional technology is challenging the sustainability of today's environment. Although some problems are coming in the way of its implementation but if we see its long term implication it's for sure we and our future generation will be benefitted. Also using green technology we can conserve our limited energy sources to some extent. In India, the demand for private transportation is alarmingly increasing because of the inadequacy of public transportation system. The development of eco-friendly and affordable public transportation solution is not therefore, a question of choice, but the need of hour. This can be solved by green technologies with proper research and development. There is a huge construction work going on in India. The concept of environment-friendly or green building needs to be adopted by developing locally relevant all-weather building technologies and construction methodologies to reduce increasing dependency on air-conditioning. Almost 70 per cent of Indian population depends on agriculture, which is one of the energy intensive sectors. Agriculture consumes about 35 per cent of the total power generated through electrically operated pump sets. It is expected that about 30 per cent of savings is possible through appropriate technology [7]. For example, larger valve can save fuel and power to draw water from the well. It has been shown that the farmers can save 15 liters of diesel every month by simply reducing the pipe height by $2 \mathrm{~m}$. The use of good quality PVC suction pipe can save electricity up to 20 per cent. Finally, Green technologies would definitely help in attaining environmental sustainability if utilized systematically.

\section{Acknowledgements}


Dr. BGR is thankful to UGC for the award of Post Doctoral Fellowship, File No. F./PDFSS-2014-15-SC-AND-7541.

\section{References}

1. www.ajcebeats.com/the-importance-of-greentechnology/

2. Monu Bhardwaj and Neelam (2015), The Advantages and Disadvantages of Green Technology, Journal of Basic and Applied Engineering Research, 2 (22); pp. 1957-1960.

3. http://www.gpnm.org/e/articles/Definition-of-GreenTechnology-by-KETTHA-Ministry-of-Energy-GreenTechnology-and-Water-a5.html
4. Sustainability and Green Technology, An e-book on strategies for sustainability authored by the Class of 2012 Massachusetts Academy of Mathematics and Science.

5. http://www.wbcsd.org/plugins/DocSearch/details.asp?M enuId $=\mathrm{NjA} \&$ ClickMenu=Lefenu $\&$ doOpen=1 \&type $=$ Do cDet\&ObjectId=Mjc4NTc.

6. http://www.unapcaem.org/publication/greentech.pdf

7. http://www.nedcap.org/index_files/ Page2210.htm.

8. http://indianexpress.com/article/india/indias-solarpower-capacity-crosses-9-gw 4510799/

9. http://mnre.gov.in/schemes/grid-connected/solarthermal-2/

\section{How to cite this article:}

Gangadhar B and Ramakrishna Naidu G (2017) ' Green Technology Vs Environmental Sustainability In India-An Overview', International Journal of Current Advanced Research, 06(03), pp. 2465-2468. 